\title{
Preconditions for bioenergy with carbon capture and storage (BECCS) in sub-Saharan Africa: the case of Tanzania
}

\author{
Anders Hansson, et al. [full author details at the end of the article]
}

Received: 10 October 2018 / Accepted: 11 November 2019 / Published online: 21 November 2019

(c) The Author(s) 2019

\begin{abstract}
Most mitigation scenarios compatible with a likely change of holding global warming well below $2{ }^{\circ} \mathrm{C}$ rely on negative emissions technologies (NETs). According to the integrated assessment models (IAMs) used to produce mitigation scenarios for the IPCC reports, the NET with the greatest potential to achieve negative emissions is bioenergy with carbon capture and storage (BECCS). Crucial questions arise about where the enormous quantities of biomass needed according to the IAM scenarios could feasibly be produced in a sustainable manner. Africa is attractive in the context of BECCS because of large areas that could contribute biomass energy and indications of substantial underground $\mathrm{CO}_{2}$ storage capacities. However, estimates of large biomass availability in Africa are usually based on highly aggregated datasets, and only a few studies explore future challenges or barriers for BECCS in any detail. Based on previous research and literature, this paper analyses the pre-conditions for BECCS in Tanzania by studying what we argue are the applications of BECCS, or the components of the BECCS chain, that are most feasible in the country, namely (1) as applied to domestic sugarcane-based energy production (bioethanol), and (2) with Tanzania in a producer and re-growth role in an international BECCS chain, supplying biomass or biofuels for export to developed countries. The review reveals that a prerequisite for both options is either the existence of a functional market for emissions trading and selling, making negative emissions a viable commercial investment, or sustained investment through aid programmes. Also, historically, an important barrier to the development of production capacity of liquid biofuels for export purposes has been given by ethical dilemmas following in the wake of demand for land to facilitate production of biomass, such as sugarcane and jatropha. In these cases, conflicts over access to land and mismanagement have been more of a rule than an exception. Increased production volumes of solid biomass for export to operations that demand bioenergy, be it with or without a CCS component, is likely to give rise to similar conflicts. While BECCS may well play an important role in reducing emissions in countries with high capacity to act combined with existing large point sources of biogenic $\mathrm{CO}_{2}$ emissions, it seems prudent to proceed with utmost caution when implicating BECCS deployment in least developed countries, like Tanzania.The paper argues that negative BECCS-related emissions from Tanzania should not be assumed in global climate mitigation scenarios.
\end{abstract}

Keywords Tanzania $\cdot$ Bioenergy with carbon capture and storage $\cdot$ BECCS $\cdot$ Negative emissions $\cdot$ Bioenergy $\cdot$ Biomass $\cdot$ Climate change $\cdot$ Least developed countries 


\section{Introduction}

Most climate scenarios compatible with a likely change of holding global warming well below $2{ }^{\circ} \mathrm{C}$ rely on negative emissions technologies (NETs). According to the integrated assessment models (IAMs) used to produce climate scenarios for the Intergovernmental Panel on Climate Change (IPCC) reports, the NET with the greatest potential to achieve negative emissions is bioenergy with carbon capture and storage (BECCS) (Beck and Mahony 2018; Fuss et al. 2014; Gough et al. 2018a, b; Harper et al. 2018). This method features in the scenarios despite only experimental scale experiences and acknowledged major uncertainties related to, for example, technological capacity, maturity and the availability of sustainable biomass. Fuss et al. (2014) estimate the required quantities of removed carbon, if guided by the estimates from the IPCC's Working Group III, to be in the range between 2 and $10 \mathrm{Gt}$ annually in 2050. Such a huge deployment would, among other things, entail serious land-use trade-offs with possibly long-lasting impacts on food security, fibre production, biodiversity and fresh water and fertilizer supply (Creutzig et al. 2015; Fuss et al. 2014; Harper et al. 2018).

Crucial questions arise about where the enormous quantities of biomass needed according to the IAM scenarios could be produced in a sustainable manner. Many IAMs deploy large amounts of BECCS in sub-Saharan Africa, and according to the Carbon Mitigation Initiative at Princeton University, Africa is attractive in the context of BECCS because of large areas that could contribute biomass energy and indications of substantial underground carbon dioxide $\left(\mathrm{CO}_{2}\right)$ storage capacities. The initiative has presented the idea that the USA could meet ambitious national emissions targets in 2050 by buying offsets from African BECCS projects, while also providing opportunities for co-benefits in Africa, such as sustainable fuels for cooking and transport (Williams and Larsen 2012).

However, estimates of large biomass availability in Africa are usually based on highly aggregated datasets, and only a few studies explore future challenges or barriers for BECCS in any detail. Technical and social challenges for the rapid up-scaling of BECCS in different socio-economic and geographical contexts have not yet been satisfactorily explored (Anderson and Peters 2016; Buck 2016; Carton 2019; Creutzig et al. 2015; Fuss et al. 2014; Geden 2015; Gough et al. 2018a, b). Buck (2016) has further argued that context-dependent factors such as national politics, land characteristics and social relations are likely to significantly determine the feasibility of BECCS, and that such factors are missing from highly generalized mitigation scenarios. This paper thus seeks to contribute to more context-sensitive knowledge about the feasibility of BECCS, with an in-depth analysis of socio-economic, geographical and institutional preconditions in Tanzania, a developing country identified by IAMs as having a large potential for large-scale BECCS deployment (Harper et al. 2018). Following Buck's (2016) suggestion that analogue cases may be the most accessible route for understanding the feasibility of BECCS, given the lack of real-world experiences of large-scale BECCS, we will explore large-scale biofuel investments in Tanzania as an entry point for a more general discussion about the feasibility of large-scale BECCS in sub-Saharan Africa.

Based on the previous research and literature, this paper analyses the preconditions for BECCS in Tanzania by studying what we argue are the applications of BECCS, or the components of the BECCS chain, that are most feasible in the country, namely (1) as applied to domestic sugarcane-based energy production (bioethanol), and (2) with Tanzania in a producer and re-growth role in an international BECCS chain, supplying biomass or biofuels for export to developed countries. 


\section{Background}

The core idea of BECCS is the growth and utilization of biomass for different industrial and energy purposes and subsequent storage of the resulting $\mathrm{CO}_{2}$ by-product in geological formations while also re-growing biomass. Because $\mathrm{CO}_{2}$ is stored both in the biomass through photosynthesis and after the biomass has been processed, the technology allows for the potential of net negative $\mathrm{CO}_{2}$ emissions. Due to its significant capital costs, it is regarded as applicable only to large point sources, primarily the paper and pulp industry, biofuel producers or combined heat and power plants. A huge drawback of BECCS is its heavy energy penalty, which means it significantly lowers the efficiency of the industrial process it is applied to (Bui et al. 2017; Jönsson and Berntsson 2012).

Tanzania is theoretically well suited for biomass generation on an industrial scale. It has long been considered a forerunner in sub-Sahara Africa in carbon forestry management (Blomley et al. 2008), and even termed an "African poster child for policy reform" with regard to forest management (Koch 2017: p. 181), while also taking the lead in the production of jatropha biofuel and influencing the international debate that followed (Arora et al. 2013; Gasparatos et al. 2015). The country has several characteristics that suggest it is also suitable for BECCS deployment, as evidenced by the recent history of Western investments in liquid biofuels and other land-based projects (Harnesk and Brogaard 2016). These projects have been motivated by the fact that $46 \%$ of the country is covered with forests, and that it possesses an abundance of unused land, a large available workforce and governmental structures that are generally perceived to be stable and supportive of foreign investment (Habib-Mintz 2010; Mwakaje 2012). Even though BECCS is currently absent as a political issue in Tanzania, its vast biomass resources, beneficial preconditions according to many IAMs (e.g. Harper et al. 2018), recent history of foreign investments, and central position in international debates on biofuels and forest management make it arguably one of the most suitable objects for a case-based investigation into the feasibility of BECCS in sub-Saharan Africa. Furthermore, it is the only African country that has been targeted for claimed investments aimed at a development of BECCS (Kemper 2015; Swedish Radio 2009).

\subsection{Analytical framework and method}

Due to the fact that BECCS lacks both a technology/science push and market pull, it can be said to lack the main determinants of emerging technologies succeeding in breaking through (Bellamy and Healey 2018; Freeman 1986). This, in addition to the fact that it does not yet exist on a commercial scale, poses challenges for how to study its hypothetical future development, thus studies of system innovations, the emergence of sustainable technologies and socio-technical transitions (Edquist 1997; Geels 2012; Metcalfe and Cantner 2003; Smith et al. 2005) are likely to be of limited value. Yet, some theoretical premises for novel technology development can be derived from such literature, and we will employ a basic analytical framework suggested by Jacobsson and Lauber (2006) for the analysis of BECCS' potential in Tanzania. As Markard et al. (2012) note, there is also a value in expanding studies of sustainable transitions to countries outside the OECD core, not least to highlight unequal power relations in technological development, that are of crucial importance for the potential implementation of BECCS in sub-Saharan Africa (Hansen et al. 2018; Lawhon and Murphy 2012; Wieczorek 2018). 
The analytical framework suggested by Jacobsson and Lauber (2006) assumes that large-scale technological transformations presuppose and entail economic, social and infrastructural transformations at different scales. First, they require institutional change, which includes the creation of policies, legislation, regulatory standards, knowledge and political structures that facilitate the emergence of a new technology and its access to technological expertise and markets. Here, we would also add the importance of informal institutions to complement and operate in the void between incomplete or inadequate formal institutions, and that may include historical memory and trust (van Assche et al. 2014). Because informal institutions are harder to detect, they may be easy to overlook, but they are often crucial in determining path dependencies of different kinds, something that Wieczorek (2018) highlights as key to understanding socio-technical innovation in developing countries.

Secondly, a new technology is dependent on the formation of markets for its breakthrough, something that is in itself closely connected to institutional change. New markets often need a period of protection, during which crucial learning processes help the technology reach commercial maturity, and incentive structures of different kinds may induce firms to enter. Here, in line with Karnøe and Garud (2012), we would highlight that institutions not only act as limiting factors or structural determinants of path dependency, but may also be seen in an alternative light as preconditions for path creation, perhaps especially so if they are weak or malleable.

Thirdly, the creation of broader constituencies and advocacy coalitions beyond purely commercial actors is necessary for technological development. Such constituencies involve non-market actors like NGOs and universities, who contribute to fostering both material preconditions and softer structures like acceptance and legitimacy. Fourthly, the entrance of new firms into the interplay of institutions, market forces and advocacy coalitions will decide the success of an emerging technology. In the context of developing countries, Marquardt et al. (2016), Nygaard and Bolwig (2018) and Sixt et al. (2018) have highlighted the importance of support and advocacy from international actors, while van Welie and Romijn (2018) stress the need to embed technological development in the local culture. Because of the still highly hypothetical nature of BECCS development as a technological system, we treat these third and fourth steps as a single step in the concluding discussion. This framework should be seen as a simple set of criteria against which we evaluate the possibilities of BECCS development in Tanzania in the concluding discussion, and it is not employed in the main literature review, which follows in the next section.

The paper is based on secondary literature that was found through the Unisearch web application. We selected literature based on its relevance according to our analytical framework and assumptions about BECCS' feasibility in Tanzania, i.e. that it is most likely to be applied in relation to ethanol production or with Tanzania acting as a provider of solid biomass for export. Thus, we included literature that pertained to geographical conditions of relevance for industrial biomass production, land-use trade-offs, case studies of biofuel projects, and formal institutional frameworks regulating biofuel production and foreign investments, all geographically limited to Tanzania.

The vast majority of texts are peer-reviewed scientific publications, but some items of particular relevance from the grey literature and from news sources were also included. The search (which included the search strings "Tanzania", "LDC", "BECCS", "bioenergy with carbon capture and storage", "SEKAB", "ethanol production", "biofuel" and "REDD+" in various combinations) generated around 60 texts which were deemed relevant after an initial brief overview and reading of the abstracts. Further texts were included using the reference lists. This first selection was then closely read and cross-analysed by all authors, allowing us to make a number of key points in relation to our research problem 
and analytical framework. It should be noted that we have used the literature review as a basis for an analysis of formal and informal institutional preconditions for large-scale BECCS in Tanzania, and that our aim has neither been to perform a comprehensive literature review nor an overview of the field or bibliometric analysis. While certain papers of potential relevance might therefore not have been included, we are confident that our main arguments are sustained by and firmly anchored in relevant literature.

\section{Background}

\subsection{Path creation preconditions for BECCS in Tanzania: ethanol or solid biomass for export}

The more recent mitigation scenarios, described by Riahi et al. (2017), which deliver a climate forcing of $2.6 \mathrm{~W} / \mathrm{m}^{2}$ in 2100 (i.e. compatible with the $2{ }^{\circ} \mathrm{C}$ goal), deploy BECCS in all world regions, including the region "Africa and the Middle East". As early as mid-century, the average deployment rate of BECCS in this region is $6.3 \mathrm{EJ}$ (i.e. $1700 \mathrm{TWh}$ ). By 2060 , all $2{ }^{\circ} \mathrm{C}$ scenarios deploy BECCS to some extent, averaging 27.4 EJ (see Fig. 1). For comparison, 0.022 EJ (i.e. $6 \mathrm{TWh}$ ) of electricity was produced in Tanzania in 2014.

The electricity grid in Tanzania is severely underdeveloped, with the majority of its population living in rural, off-grid or isolated grid areas (Felix and Gheewala 2012; Msyani 2013). Electricity makes up a fraction of the country's primary energy supply (Msyani 2013; Odhiambo 2009), and only approx. 15-30\% of the Tanzanians have access to electricity, a vast majority of them are living in urban areas (Amars et al. 2017; Aly et al.

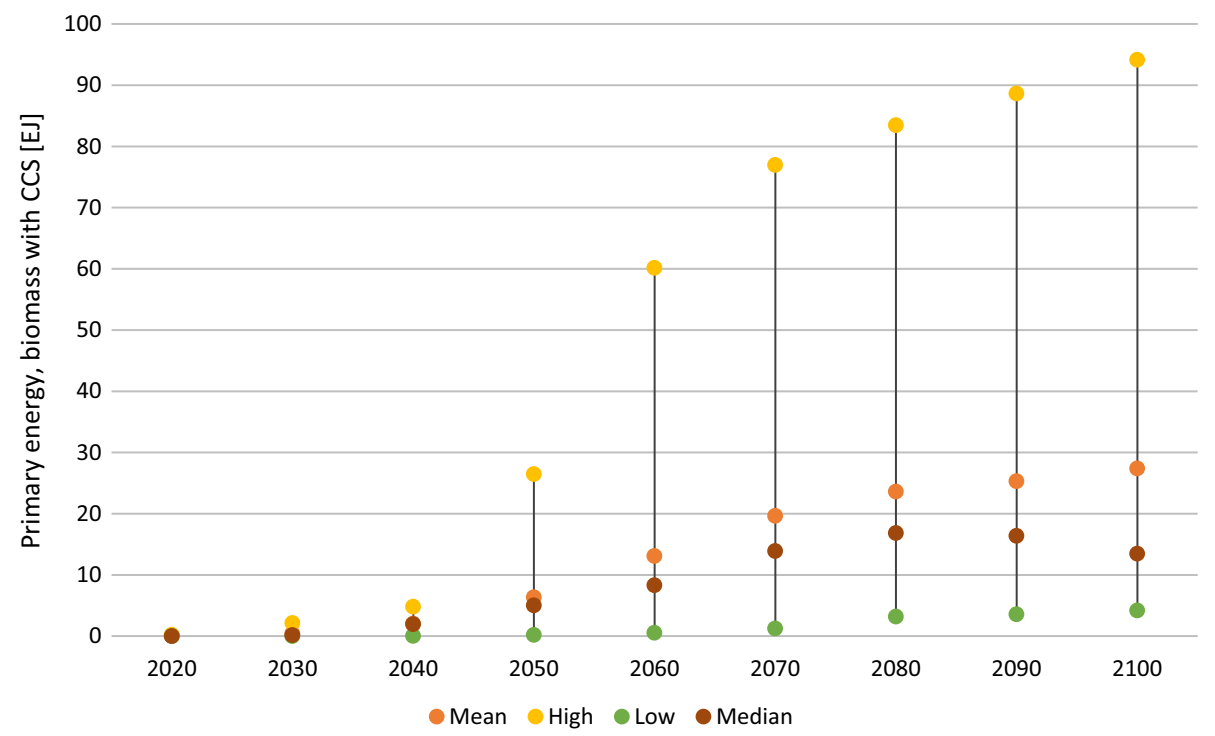

Fig. 1 Use of BECCS in the Middle East and Africa in the Shared Socio-economic Pathways Database's scenarios $(n=19)$ compatible with a forcing of $2.6 \mathrm{~W} / \mathrm{m}^{2}$ in 2100 (i.e. $2{ }^{\circ} \mathrm{C}$ compatible) 
2017). At present, the Tanzanian energy system is dominated by biomass as a cooking fuel, which represent well over $80 \%$ of total energy consumption (AfDB 2015; Odhiambo 2009). At the same time, biomass contributes well below $1 \%$ to electricity generation; most electricity is instead generated from natural gas fired thermal power plants and hydropower (Amars et al. 2017). Increasing the level of access to electricity is highly prioritized for the Tanzanian government. However, government plans for electrification centre on fossil fuels and an ambition to vastly expand the country's large-scale hydroelectric resources (Amars et al. 2017; Bhati and Koshy 2018; Kichonge 2018). The official generation expansion plan assumes that in $2025,75 \%$ of the power production will be supplied by fossil fuel fired power plants, $20 \%$ by hydro and $5 \%$ by other renewables (Aly et al. 2017). Part of the plans for a $75 \%$ fossil fuel based electricity generation, approx. 26 percentage points, is coal-based. Up to $8 \%$ of this could potentially be co-fired with biomass without necessitating separate fuel system preparation or delivery systems (Demirbas 2003). Yet in general, the prospects for a development of a domestic bioenergy-based power system in Tanzania seem slim. Furthermore, because the paper and pulp industry is limited to a single facility, this avenue for BECCS is also restricted.

In general, the prospects for $\mathrm{CO}_{2}$ storage are deemed to be low in the onshore sub-Saharan Africa, but suitable geological $\mathrm{CO}_{2}$ storage basins may exist onshore in the coastal areas of Tanzania. Storage potentials are not well explored, however, due to a lack of experience of oil and gas extraction in those areas (Haszeldine 2006). It has been suggested that the neighbouring country in the south, Mozambique, has extensive storage capacity, more than enough for its future domestic needs. The northern region of Mozambique has been identified as one of the most promising areas for extracting natural gas and coal, especially the Rovuma basin (235-470 $\mathrm{Mt} \mathrm{CO}_{2}$ ) (Global CCS Institute 2015), but none of the major extractive industrial actors have been promoting geological $\mathrm{CO}_{2}$ storage here. Sasol, the major South African chemical and energy company, is investing heavily in natural gas extraction in Mozambique and acknowledges climate change as a paramount challenge. It has an active interest in carbon capture and storage (CCS) as partners of "The South African Centre for Carbon Capture and Storage" and as stakeholders in "CCS forerunners Technology Centre Mongstad" in Norway. The viability for geological storage of $\mathrm{CO}_{2}$ is currently claimed to be investigated by Sasol, but only domestically in South Africa. Natural gas extraction in Mozambique is presented by the company as an opportunity to displace more carbon intensive fuels like coal, rather than enabling $\mathrm{CO}_{2}$ storage (Sasol 2018).

Very large natural gas resources (37 trillion cubic feet) were discovered off-shore in 2010, in the south eastern regions of Tanzania, bordering Mozambique. These resources vastly outnumber the domestic demand for natural gas, and consequently, the gas resources can only be fully monetized through exports of liquefied natural gas. Several major international energy companies have been invited by the government to form joint ventures, to facilitate the construction of the multi-billion dollar infrastructure needed to exploit the resources. This would constitute one of the continent's most capital-intensive infrastructure projects, estimated to cost at least US\$ 20-30 billion. However, since the discoveries were made in 2010, the government's view on revenues and ownership structures has changed towards a more nationalistic stance, with more control left to domestic and statecontrolled companies and a shift in focus from institutional capacity building to maximizing benefits for Tanzania (Hundsbaek Pedersen and Bofin 2019). According to Hundsbaek Pedersen and Bofin (2019), the driver for the radical change was the anxiety that foreign actors would extract the resources without contributing to the Tanzanian economy, as has 
been the case historically. This shift in focus was formalized in the Petroleum Act of 2015 and three Sovereignty Acts of 2017, ${ }^{1}$ which among other things declared national sovereignty over natural resources and disallowed companies to take disputes to international arbitration. Consequently, several major international actors have ongoing disputes with the Tanzanian government. Certainly, the unpredictability that has followed the publication of the Sovereignty Acts has made Tanzania less attractive for foreign investments in largescale infrastructure (Hundsbaek Pedersen and Bofin 2019), and will most likely also keep the integration of carbon storage in the slowly emerging Tanzanian fossil fuel sector off the table for the foreseeable future.

Instead, in the following, we discuss the avenues ahead for the arguably least problematic options for integrating Tanzania in a future BECCS system. First, in spite of the acknowledged challenges of taking advantage of suitable storage sites in the region, we discuss the technically least complex and least costly option for capturing relatively large amounts of $\mathrm{CO}_{2}$, and secondly, we discuss the growth of biomass for export within an international BECCS system, which would reposit the challenges and main responsibility of storage to developed countries.

As the fermentation of sugar gives rise to almost pure $\mathrm{CO}_{2}$ fumes $(99 \%$ purity in the reactor), capturing $\mathrm{CO}_{2}$ from ethanol production is generally considered among the cheapest options for BECCS (Moreira et al. 2016). The techno-economic potential for ethanol production in Tanzania, in different scenarios, has been assessed at 6-26 million litres (1) annually from sugarcane molasses (a by-product from the production of sugar) and an additional 15-79 million 1 annually from sugarcane juice, i.e. a combined potential of 21-105 million 1 annually (Quintero et al. 2012). As ethanol weighs approx. $0.8 \mathrm{~kg} / \mathrm{l}$, the production potential corresponds to 17-84 million $\mathrm{kg}$ of ethanol annually. Fermentation resulting in $1 \mathrm{~kg}$ ethanol releases approximately $0.96 \mathrm{~kg} \mathrm{CO}_{2}$ (Moreira et al. 2016). The scenarios for ethanol production, thus, correspond to releasing approx. 0.016-0.081 million metric tonnes (Mt) of biogenic $\mathrm{CO}_{2}$ annually. This can be compared to Tanzania's total emissions in 2014 of $290 \mathrm{MtCO}_{2 \mathrm{eq}}$ including land use, land use change and forestry (LULUCF), and $80 \mathrm{MtCO}_{2 \mathrm{eq}}$ excluding LULUCF. However, there are possibilities to combine different scenarios to further increase production (Quintero et al. 2012). Thurlow et al. (2016) conclude that the economic incentives for ethanol production in Tanzania are strong, indicating that ethanol production could expand relatively rapidly under the right market conditions. Eshton and Katima (2015) show that under the right market conditions and optimization of cultivation practices, reducing the need for chemical fertilizers, biofuels may, if not exported, reduce the GHG emissions by $70 \%$ compared with fossil fuels, while also increasing Tanzanian energy security. However, they also emphasize that Tanzania has low food productivity, and consequently, large investments in bioenergy crops could have negative socio-economic implications. Figure 2 shows total sugar production in Tanzania from $2007 / 2008$ to $2016 / 2017$ indicating annual variability in total sugar production, with a slightly positive trend starting from 2011/2012.

Potentially, ethanol could also be used for cooking, which could prove to be a crucial improvement from an environmental perspective. Both rural and urban Tanzanian households are heavily dependent on firewood or charcoal for heating and cooking, with Felix and Gheewala (2011) reporting $94 \%$ of all households and $78 \%$ of households in Dar es

\footnotetext{
1 The Natural Wealth and Resources (Permanent Sovereignty) Act, the Natural Wealth and Resources (Review and Re-Negotiation of Unconscionable Terms) Act and The Written Laws (Miscellaneous Amendments) Act.
} 


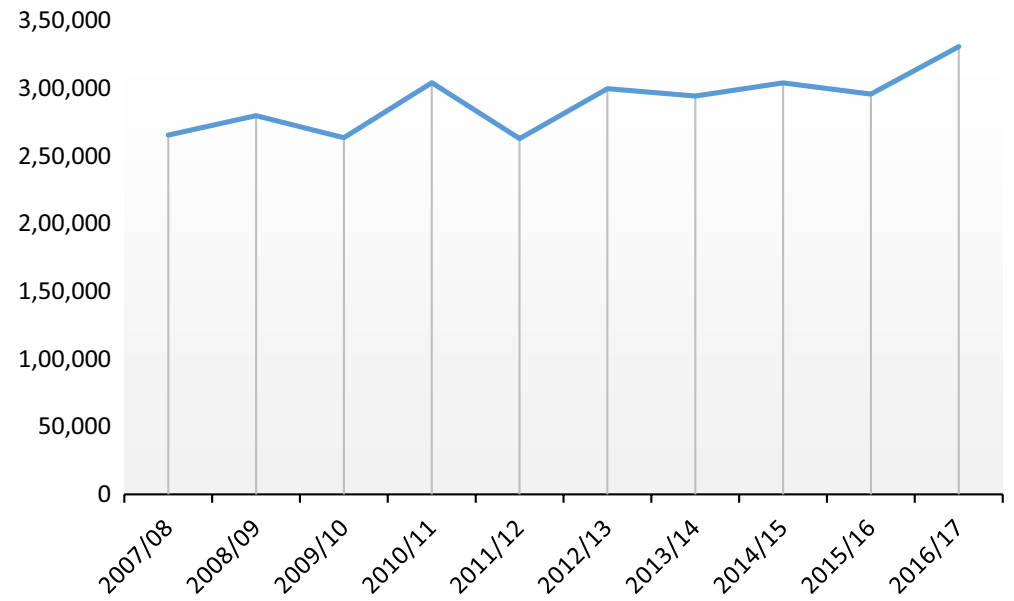

Fig. 2 Total sugar production from 2007/2008 to 2016/2017

Salaam to be reliant on the fuel. In 2000, total consumption of charcoal in the country was estimated at 750,000 tonnes (Sheya and Mushi 2000), and Odhiambo (2009) has reported $90 \%$ of total energy consumption to be biomass-based. Apart from causing health problems through air pollution, this enormous level of charcoal production puts heavy pressure on the forest, with deforestation increasingly being acknowledged as a problem. Government attempts to impose fines on charcoal production have largely failed due to difficulties in regulating this unofficial economy, and substituting charcoal for liquefied petroleum gas (LPG) is only an option for the relatively rich (Felix and Gheewala 2011).

Thus, there is a potential side-benefit to be found in implementing BECCS in relation to expanded use of ethanol domestically in Tanzania. Just as importantly, however, increased production of biomass for biofuel purposes risks results in positive emissions when all factors are considered, and thus further environmental degradation (Harper et al. 2018; Romijn 2009). Apart from causing biodiversity stress, deforestation is the major source of greenhouse gases in Tanzania. Agriculture, forestry and other land uses (AFOLU) in Tanzania account for $93.2 \%$ of total emissions, which dwarfs the emissions from the other sectors. Energy contributes to $3.8 \%$, waste management to $1.5 \%$, and industrial processes and product use to $0.5 \%$. Deforestation and forest degradation account for the largest emissions in the AFOLU sector, with approximate annual emission of $37 \mathrm{MtCO}_{2 \mathrm{eq}}$ (URT 2014, 2017).

A BECCS supply chain does not need to be confined to one single country. Peters and Geden (2017) illustrate a potential BECCS system with biomass harvesting in Cameroon exported to the UK for combustion and carbon capture and subsequent permanent storage in Norway. Given that BECCS necessitates a long-term perspective, spanning decades or even centuries, the prospect of involving several countries with vastly different motives and governance cultures would be likely to pose major challenges for the creation of a robust and reliable system for measurement, reporting and verification. Nevertheless, the division of the system components of BECCS across several countries is mentioned frequently in the BECCS literature (Gough et al. 2018a, b; Grönkvist et al. 2010; Peters and Geden 2017; Williams and Larsen 2012). Honegger and Reiner (2018) analyse at length how international policy instruments, primarily Article 6.4 of the Paris Agreement, could mobilise the 
financial support needed for deploying NETs in developing countries, in a least-cost and flexible way that take the partaking countries' various stages of development into account.

The idea of African countries acting as suppliers of biofuels or a source for biomass re-growth has already raised concerns. In Bonn in May 2016, at the first session of the UN Framework Convention on Climate Change after the Paris Agreement was concluded, an intense debate took place when a few African networks raised fears that negative emissions technologies would result in land-grabs on the African continent (Guillemot 2017). Anderson and Peters (2016) raise concerns over global inequity from another angle. They claim that an eventual failure to deliver NETs, as envisioned in most IAMs, would strike the vulnerable low-emitting countries hardest. If prioritizing equity, risk aversion and aspiring to avoid moral hazard, they claim, the global climate mitigation agenda should instead rest on the premise that NETs will not deliver at scale (see also Carton 2019). Implementing BECCS would therefore entail serious difficulties and risks.

From an optimistic viewpoint, it could be argued that a path creation for BECCS would create an opportunity for regulatory improvement, given that the current forest and land management situation in Tanzania is precarious (Bhati and Koshy 2018; Karnøe and Garud 2012). To better understand the preconditions of such an optimistic scenario coming to fruition, we will therefore summarize findings from the literature about the formal institutional framework relevant for a future BECCS system in Tanzania, as well as empirical evidence from biofuel projects that point towards the existence of important informal institutions (van Assche et al. 2014).

\section{Formal institutions governing biomass development}

\subsection{International formal institutions related to climate change}

Internationally, the expectations on developing countries to contribute to global mitigation efforts have increased over the last decade. The Paris Agreement is perhaps the most prominent example of this trend, as it is the first globally applicable climate agreement expecting all contracting parties to contribute to emissions reductions and to undertake adaptation measures to avoid dangerous anthropogenic interference with the climate system. The Paris Agreement thus provides a policy objective clearly relevant to BECCS: to hold global warming well below $2{ }^{\circ} \mathrm{C}$ by 2100 and, in the second half of the century, to balance global emissions and uptakes. This goal will require changing societies on transformational scales, building societal and ecosystem resilience by, among other things, achieving net-zero emissions of greenhouse gases sometime after 2050. However, being labelled a least developed country (LDC), Tanzania is subject to relatively low pressure from international politics to adopt decarbonization leadership; mitigation actions in Tanzania are expected to primarily be supported by international means of implementation. Thus, the international level provides contradictory incentives for BECCS in Tanzania: while the Paris Agreement has created pressures globally to stimulate the development of NETs, international mechanisms do little to facilitate the establishment of national-level institutional structures that are conducive to foreign investment in such technological developments. The IPCC's accounting methodologies and guidelines for emissions are developed for national entities, and have difficulties capturing and mirroring the complexity of multinational or even global BECCS systems and supply chains (Gough et al. 2018a, b). Gough et al. (2018a, b) have further 
identified goal conflicts between the targets concerning loss of natural habitats and restoration of degraded areas adopted by the Convention on Biological Diversity in 2010targets which are not considered in the land-use scenarios applied in the IAMs - and mitigation targets premised on expanded biofuel use. Gasparatos et al. (2015) similarly argue that knowledge about the multitude of targets and indicators that exist on different policy levels is incomplete and fragmented, making management of the significant trade-offs difficult.

The incentives gap between policy levels can be illuminated by looking at the most central components in the international toolbox for technology development and resilience building in LDCs. The most relevant of these is the Kyoto Protocol's Clean Development Mechanism (CDM), which is an instrument of tradable emissions credits. Developed countries may invest in CDM projects in developing countries, prove emissions reductions compared to a baseline and generate tradable emission rights. In 2011, the UNFCCC decided to include CCS in the CDM. However, thus far, not one single methodology for a CCS CDM project has been approved. Such approval is also unlikely in the future for at least two reasons: (1) the market for certified emission reductions from CDM has virtually collapsed with the decline in demand, and (2) the requirements for approval of CCS methodologies under the CDM are unusually strict, involving host country domestic regulations covering, e.g. site selection and characterization, access rights to storage sites, redress for affected entities and liability (Dixon et al. 2013). As noted by Zakkour et al. (2014), the approval of CCS CDM rules in late 2011 coincided with a downturn in interest in the CDM, which in turn undercut the potential to spur the development of BECCS in Tanzania. At present, discussions are under way on how a new market mechanism, similar to the CDM of the Kyoto Protocol, should be operationalized under the Paris Agreement (e.g. Greiner et al. 2017).

Similarly, Nationally Appropriate Mitigation Actions (NAMAs) and REDD+, which are both instruments used for incentivizing various types of biomass operations, are driven more by donor than by market logic. The same applies to climate-related official development aid. The problem with this logic regarding BECCS in Tanzania is that donors generally seek to avoid institutionalizing aid (Fridahl et al. 2015), while BECCS would necessitate long-term commitment of capital for both initial investments and operation. BECCS is generally characterized by high operational costs and few, if any, benefits beyond its contribution to the global mitigation effort. Even the most promising low-cost alternatives for BECCS, i.e. ethanol production, would require capital to cover the cost added to normal operations (Moreira et al. 2016). As long as the option to sell carbon credits in an international market remains unfeasible and donors are unwilling to provide long-term aid to cover operational costs, the pressure from international law on Tanzania to implement BECCS will remain low and unconducive. In other words, while the international policy objectives have become clearer, the instruments for fulfilling such objectives in LDCs do not support BECCS.

Yet, accounting rules developed by the IPCC and agreed by the UNFCCC can incentivize BECCS. In the national greenhouse gas inventories, negative emissions resulting from BECCS can be used to offset positive emissions by pooling within or between sectors. As such, BECCS can be used to comply with international commitments. However, even if the accounting rules may incentivize BECCS at national level, the typical operator, i.e. subnational entities or businesses, is not given incentives from national accounting rules since it is governments-not subnational entities - that are responsible for compliance under the UNFCCC. Furthermore, using such an option for compliance also requires that the mitigation target is extremely ambitious and that low-cost mitigation options have been 
exhausted, rendering higher cost options such as BECCS viable. Neither of these conditions have been fulfilled in Tanzania. Given the country's other overriding priorities and its low international responsibilities for mitigating climate change, it seems highly unlikely that these international factors will incentivize the Tanzanian government to direct investments into BECCS.

\subsection{Domestic formal institutions related to climate change}

Domestically, a large package of climate-related strategies, policies and laws have been adopted in Tanzania. The most immediately relevant is the 2012 Climate Change Strategy, preceded by Tanzania's 2007 National Adaptation Program of Action and subsequently followed by the 2013 Agriculture Climate Resilience Plan (sectorial response to the strategy) and the National REDD+ Strategy (forestry conservation and sustainable management). Soon after, in 2015, Tanzania also submitted its Intended Nationally Determined Contribution (INDC) to the UN Paris Agreement. All of these are structured under the Tanzanian Development Vision 2025, agreed in 1999 with the aim of transforming Tanzania into a middle-income, semi-industrialized country by 2025 . The vision was first detailed in parallel strategies for economic development and eradication of poverty together with five-year development plans focusing more on investments in human resources and capital, the first having been initiated in 2011, all of which informs the Climate Change Strategy and its sectorial responses. By 2016, the different strategies had become sufficiently similar to be merged into a coherent second five-year development plan, now organized under a long-term perspective plan initiated to provide a clearer direction for the short- and mid-term strategies, later enabled by the brief and relatively abstract Vision 2025 (Government of Tanzania 2012). Vision 2025 sets domestic goals aspiring to become a middle-income and semi-industrialized country by 2025 . This goal requires a transformational change of Tanzania's socio-technical systems through, for example, policy development, eradication of energy poverty, expansion of its educational system and diversification of the economy to avoid overdependence on primary resources, especially in climate-sensitive sectors (Government of Tanzania 1999).

The Climate Change Strategy constitutes significant progress in the much-needed work of identifying Tanzania's climate vulnerabilities and possible response measures, and to start making the general 1997 National Environmental Policy and 2004 Environmental Management Act more climate specific. There are still several steps to take to turn the strategy into policy and possibly law, especially when it comes to being more specific and prioritizing interventions (Yanda et al. 2013).

\subsection{Formal institutions regulating ethanol, other biofuels and solid biomass}

A BECCS ethanol technical system in Tanzania would, if not intended purely for domestic appliances, have to be adapted to international market standards. Tanzania is exempted from import tariffs, which means that Tanzanian ethanol would be competitive with Brazilian ethanol despite higher production costs. However, access to the EU market is also dependent on Tanzanian producers' ability to meet the EU's sustainability criteria. This holds both for ethanol and for solid biomass fuels (Widengård et al. 2018). Among other things, this means that bioethanol must achieve greenhouse gas savings of $60 \%$ for new production plants and 50\% for old plants in comparison with fossil fuels. It also means that converting land with high carbon stocks to grow biomass intended for biofuel production is 
prohibited. In Tanzania, this means that accessing the EU market requires limiting production to converted grassland in combination with mitigation measures to combat processrelated emissions.

This legislation would conflict with the immediate domestic economic incentives for ethanol production. Thurlow et al. (2016) have evaluated the economic potential for ethanol production in Tanzania, including scenarios under emission constraints, and found great potential for economic growth and poverty reduction, especially in scenarios where smallholders in outgrower schemes are used. However, if the emission constraints are also factored in, to contribute less to climate change and to try to meet sustainability criteria to access the EU export market, it would make more economic sense for Tanzania to use mixed farming systems including large-scale plantations with higher productivity and, thus, less need for clearing land for the purpose of cultivating sugarcane (Thurlow et al. 2016).

The global market price for ethanol is also dependent on legislation external to Tanzania. For example, it has been shown that the global market price for ethanol in 2002-2010 was largely determined by a tax credit to fuel blenders for each entity of biofuel mixed with fossil fuels in the USA as well as consumer biofuels tax exemption in Brazil (Rajcaniova et al. 2013). Whether Tanzanian ethanol is competitive on a global market therefore depends not only on achieving low production and transportation costs but also on subsidies provided in other ethanol producing countries. Such complex market dynamics ought to hold true for solid biomass, too.

Furthermore, the world market price of ethanol or solid biomass is vulnerable to environmental changes. Sugarcane, for example, is very sensitive to variable climate (Everingham et al. 2002). If climate change impacts negatively on the production of sugar in, for example, the large Brazilian sugar and ethanol district of São Paulo, this could drive global market prices up. Therefore, climate change can affect biomass and biofuel production in Tanzania both directly, and indirectly through global market swings following impacts in other parts of the world. Such effects may work both positively and negatively in terms of producer opportunities.

In Tanzania, the acquisition of land for biofuel development purposes is regulated by the Land Act and the Village Land Act, both adopted in 1999 and implemented in 2001. Together they regulate the use of village land, which constitutes $70 \%$ of the total land area, and general land, constituting $2 \%$. For an investor to be able to acquire village land for plantations of biofuel, the land must first be transformed into general land by an act of government, and then leased for a maximum of 99 years (Arora et al. 2013; Massay 2016).

Reclassifying village land into general land can be done by the president in accordance with section 4 of the Land Act. This involves transparent and participatory processes, adequate compensation and assurances that the land will be reverted to villagers in the event of, for example, failure to carry out investments as planned. In practice, however, the process of reclassifying land is often deemed intransparent, compensation inadequate and monitoring of the investors' compliance with the planned land use changes unsatisfactory. Several examples exist of situations when land is reclassified and leased to international biofuel investors, but the investments are not carried out as promised. In these situations, it has proven hard for farmers and villages to reclaim their rights to manage the land for farming, gracing or other original purposes (Kijazi et al. 2017; Tenga 2015).

Domestic laws and guidelines have also been developed to regulate the production of biofuels. In 2006, A National Biofuels Task Force was established aiming at developing legislation and policies for the rapidly expanding biofuel market. The energy sector in Tanzania is guided by the National Energy Policy of 2015. The policy fosters sustainable 
technology for energy development and discourages unsustainable practices such as deforestation for energy development. Despite its broad coverage of various energy sources, the policy does not provide clear policy statements or strategies for bioenergy development (Boesen et al. 2017). In addition, electricity policy is formulated in master plans, most recently the electricity master plan of 2016 . From six scenarios, one with an electricity mix dominated by gas and coal is deemed to be the most economically viable by the government. Nonetheless, significant uncertainties remain around how such a scenario could be implemented as the plan is lacking in feasibility studies, not least regarding how to transmit electricity from large energy sources located in southwest and southeast to load centres in the northwest and northeast, and most of the projects envisioned by the 2012 plan have never made progress (Bhati and Koshy 2018).

Despite the lack of a focused energy policy, biofuel development in Tanzania gained momentum after 2010 with the government and other key stakeholders being keen to make use of the investment opportunities provided by international mitigation efforts. At least since 2012, official visions have circulated that designate a future role for Tanzania as a world leader in biofuel production and export (Mwakaje 2012). These visions have been aligned to neoliberal policies pursued ever since the mid-1980s, aimed at reconfiguring Tanzania as a market open for international capital (Arora et al. 2013). Pressure for investments in bioenergy has been increasing steadily primarily due to international interest, and not due to local market demand or the national policy frameworks. The launch in 2010 of the Southern Agricultural Growth Corridor of Tanzania (SAGCOT) is one direct result of such international interest and pressure. This investment programme, established with the aim of combining profitable farming and safeguarding ecosystem services, was developed amid growing interest from international donors in ambitious private-public partnerships in Africa, typically involving big multinational investors and aiming to facilitate capital inflows to large-scale projects (Arora et al. 2013; Brüntrup et al. 2016; Engström 2018; Willoughby 2014). Furthermore, the Ministry of Energy and Minerals has developed guidelines to facilitate biofuel developments, on the assumption of the existence of 4 million hectares suitable for biofuel investment (Mshandete 2011).

Nevertheless, studies point to the domestic guidelines and regulations being vague and difficult to implement, to the detriment of both local populations and foreign investors (Arora et al. 2013; Brüntrup et al. 2016; Sulle and Nelson 2009; Vermeulen and Cotula 2010). As a result, biofuel development in Tanzania can be said to have been advancing in the absence of national policies (Mshandete 2011; Boesen et al. 2017), and the experiences of biofuel developments in Tanzania can therefore be understood as determined to a large extent by informal institutions that complement, modify or supersede weak formal institutions (e.g. Greif 2006; North 2005). In the following, we will turn to a number of such experiences and reflect on what they reveal in terms of informal institutions in Tanzania.

\section{Experiences from commercial projects and aid: the importance of informal institutions for biofuel and biomass production projects}

Biofuel-related projects, mainly biodiesel and bioethanol, have been present in Tanzania for a long period, and over the years many investors have shown an interest in increasing their level of financial commitment in bioenergy related activities (Mshandete 2011; Okonko et al. 2009). It should, however, be stressed that as Martin et al. (2009) point out, many of these initiatives have been poorly documented and that, therefore, there is 
significant uncertainty surrounding the extent of the country's biofuel endeavours (see also Mwansasu and Westerberg 2014). Nevertheless, the projects that have been documented do provide some important experiences in relation to a potential BECCS system based on ethanol or solid biomass production in Tanzania.

Most of the investments have been motivated by international policy shifts related to fossil fuel replacement, and the developments in Tanzania have therefore been determined largely by external forces (Martin et al. 2009; Mshandete 2011). Such externally driven projects include the British-owned CAMS Agri-Energy Tanzania Ltd and the Spanish Abengoa Bioenergy that in the early 2000s announced plans to jointly produce 250 million 1 of ethanol annually from sweet sorghum (Locher and Sulle 2013), corresponding to about $0.2 \mathrm{MtCO}_{2}$ annually.

The international interest in biofuel production has caused severe strain on local communities in Tanzania due to the gap between, on the one hand, vague official policies aimed at facilitating foreign investment, and, on the other hand, local institutional capacity. A lack of central oversight and monitoring, projects with little backing from local stakeholders, and local authorities lacking the necessary expertise have often meant that biofuel projects result in conflicts over competing land uses and inferior technology choices (Jumbe et al. 2009; Mshandete 2011; Mwansasu and Westerberg 2014; Rascack 2014; Boesen et al. 2017). Brüntrup et al. (2016) further claim that the success rate for projects implemented under the SAGCOT programme has been very low, with an unfavourable business environment, abusive bureaucracy, lengthy and complicated communication with authorities and fraud cited as reasons. Bergius et al. (2018) conclude that SAGCOT had a flawed design from the start, with smallholders assumed to be ineffective and in need of modernization.

The biofuel boom has further revealed severe problems with the official statistics related to land use in Tanzania. What was assumed to be unoccupied land suitable for biofuel plantations has often been found to be occupied and used, albeit sometimes in a low-intensive fashion (Olwiga et al. 2015). In an extensive assessment of land statistics in Tanzania, Exner et al. (2015) conclude that the terms "marginal land" and "unused land" are misleading and even manipulative. The terms emanate from either capitalistic-economic or statebureaucratic narratives, and obscure what are considered irrelevant user groups. These findings contradict the explicit and sometimes implicit assumptions of the World Bank and the Food and Agriculture Organization of the United Nations (FOA) that large areas of unused land are available in sub-Saharan Africa for commercial agriculture and integration into the global trade (Exner et al. 2015), and arguably also the land-use scenarios applied by the IAMs.

While the Village Land Act constituted an attempt to safeguard local communities against land grabbing, the formal institutions adopted under it have proven to be vastly underequipped to handle the increasing number of land conflicts between communities and investors, as well as between farmers and pastoralists. In April 2015, the District Land and Housing Tribunals had 18,033 cases pending and received on average 11,542 new ones each year, while the responsible governmental department, the Ministry of Lands, has been severely under-resourced, receiving zero funds for the budget year 2014/2015 (Massay 2016). At the same time, the fragmented structure of the judiciary system has meant that regulations are enforced and interpreted unevenly across institutions (Kashaigili and Nzunda 2010; Lund et al. 2006; Massay 2016; Sulle and Nelson 2009). In the absence of formal institutions regulating permission processes, applications have been approved and denied on an ad hoc basis (Martin et al. 2009), and land transactions have proven problematic both for local communities and for investors, despite the existence of a formally progressive land transactions legislation (Brüntrup et al. 2016; Sulle and Nelson 2009; 
Vermeulen and Cotula 2010; Zirulnick 2015). The lack of clear regulatory structures compromises project planning, as important steps such as application writing, permission granting and taxation are governed through informal institutions (Mshandete 2011).

The recent hype surrounding jatropha plantations is illustrative of how a sudden interest from foreign investors may cause a wave of development projects that subsides quickly when the technology fails to take off (van Eijck et al. 2014; Habib-Mintz 2010; Mwansasu and Westerberg 2014; Romijn and Caniels 2011; Sulle and Nelson 2009, 2013). Evaluations have shown that contrary to the plans to use marginal land, many agrofuel investors chose to locate their plantations on well-watered fertile land, which reportedly increased food prices (Mshandete 2011). Renzaho et al. (2017) further conclude that jatropha plantations often resulted in irreversible environmental damage. Expectations were initially great from both international investors and the Tanzanian government, but implementation revealed crucial gaps between different institutional levels that acted as barriers to technological learning, which was aggravated by a lack of trust from local communities in investors. The failure of the government to pursue a consistent policy favouring jatropha plantation that went beyond facilitating foreign investments meant that the Tanzanian jatropha industry eventually ground to a halt in the face of growing criticism of individual projects and the risk of competition for agricultural land (Arora et al. 2013).

Furthermore, the focus on ambitious private-public partnerships has, in the absence of sufficient institutional protection for small-scale farmers, given disproportional structural benefits to centralized and already privileged farms, and has risked increasing the rural poor's vulnerability to market swings (Willoughby 2014). The regulatory framework has often proven insufficient to protect local inhabitants against being evicted to make space for biofuel projects, leading to resentment and resistance towards business models involving centralized plantation strategies (Hultman et al. 2012; Boesen et al. 2017).

Similar scepticism towards aid-driven projects has been reported elsewhere, with local stakeholders viewing aid as a form of neo-colonial endeavour involving teams of foreign experts who are insensitive to cultural differences (Fridahl et al. 2015). Koch (2017) argues that in the case of aid-driven, forest related projects in Tanzania, the discrepancy between the formal policy framework and the actual experiences on the ground is usually explained by deficient resources (that responsible authorities lack qualified staff, funding or facilities to make sure the existing regulations and policies are pursued), corruption or conflicts of interest. In contrast to the conventional explanation that deficient budgets and capacity shortfalls are the main reasons for failure, Koch (2017) finds that development aid often leads to implementation failure due to the fact that decision-makers adopt a strategy of tactical manoeuvring, by which they officially adjust their agendas according to donors' aspirations but lack a genuine ambition to implement the new policies, thus leveraging resource flows and securing autonomy. In line with this, Tanzania's REDD+ policy is claimed to be another "conservation fad" serving the purpose of reinforcing and benefitting the local elite, and maintaining business as usual (Lund et al. 2017). Jacob and Brockington (2017) and Nantongo (2017) draw similar conclusions, but maintain that new modes of forest governance, besides primarily benefitting the elite, can also provide a fair share of the benefits to most of the villagers (cf. also Brüntrup et al. 2016; Renzaho et al. 2017). However, Nantongo (2017) emphasizes that the outcome is highly context dependent, which makes flexibility in implementation vital. 


\subsection{The case of SEKAB}

An illustrative case in relation to a potential BECCS system in Tanzania is the project developed by Sweden's SEKAB (Svensk Etanolkemi AB). The case displays most of the problems touched upon above, and furthermore, it is the only project in Africa to date that has been designated as a BECCS project (Kemper 2015).

In 2005, the Swedish municipal company Norrlands Etanolkraft AB bought a majority of the shares in SEKAB, after which the company embarked on an international expansion. $^{2}$ In 2006, it signed an agreement with the government of Tanzania to lease 20000 hectares of supposedly abandoned land outside the city of Bagamoyo in the Rufiji District, with the prospect of following this with additional investments in the Rufiji Delta in the southern parts of the country, totalling more than 200,000 ha (Bergius et al. 2018). The Rufiji Delta has many characteristics typical of Tanzania, and the challenges are thus likely to be similarly reflected in other regions of the nation, according to Mwakaje (2012). Initially, 10000 ha would be used for an ethanol plantation that would yield 1 million tonnes of harvested sugarcanes within 10 years of starting operation (Franke et al. 2010, Zirulnick 2015). Using the potential for ethanol production as specified by Thurlow et al. (2016) and process emission data from Moreira et al. (2016), ${ }^{3}$ this corresponds to production of about 69.4 million 1 ethanol and process emissions of about $0.05 \mathrm{MtCO}_{2}$ annually. The more ambitious, long-term plan was to export 10 million tonnes of ethanol to Sweden by 2030 and build one factory every year between 2010 and 2025 .

Swedish law restricts municipalities to only doing business within their borders, with a few exceptions for exporting knowledge and services and for international aid, and questions about the legality of SEKAB's investment in Tanzania were therefore raised. Although the Swedish administrative court ruled to allow the SEKAB investment on the basis that it was related to electricity production and could therefore be allowed as an exception according to the municipal legislation, ${ }^{4}$ the legal doubts dissuaded continued municipal financial support. Thus, in 2009, the municipality withdrew from Tanzania by selling its share of SEKAB to EcoEnergy Africa AB (in turn owned by EcoDevelopment in Europe $\mathrm{AB}$, a minority shareholder in SEKAB) for $400 \mathrm{SEK}$ (approx. €40). The concurrent downturn in global ethanol prices also influenced the municipal decision, as did a domestic debate in Sweden about the negative socio-environmental effects of large-scale ethanol production (e.g. Bergius et al. 2018).

It also became evident that the land was not abandoned as was first assumed, and even though local farmers were consulted by the company, they claimed they had not received compensation for their loss of land (Zirulnick 2015). Around the same time, the company African Green Oil (AGO) negotiated with six villages in the Rufiji District on 30,000 ha of land, ending up with just 2800 ha for the company, an episode which further reveals the gap between investors' ambitions and the amount of land actually available. In a thorough review of methods for assessing land availability, Mwansasu and Westerberg (2014) concluded that biofuel investments in the district are only possible if it is assumed that

\footnotetext{
2 See Engström (2018) for a comprehensive and critical analysis of the case.

3 That is, an ethanol conversion ratio of $69.4 \mathrm{l} / \mathrm{t}$ sugarcane, a density of ethanol of $0.8 \mathrm{~kg} / \mathrm{land}$ and process emissions of $0.96 \mathrm{~kg} \mathrm{CO}_{2} / \mathrm{kg}$ ethanol.

4 Law 1997:857 on Electricity; Law 2009:47 on Certain municipal authorities; the Municipal Act 2017:725; Law 2001:151 on Municipal export of services and municipal international aid.
} 
available land is unused and unoccupied and that the investors have applied adequate methods for assessing available land.

Complaints from NGOs and local farmers saw the project grind to a halt, and the long delay eventually resulted in the Swedish International Development Cooperation Agency (SIDA) withdrawing its conditional credit guarantee support (Zirulnick 2015). Criticism was also directed at SEKAB for influencing the Tanzanian government in setting up its National Biofuels Task Force in 2006, in parallel with the project initiation. The task force was accused of not being neutral and of including SEKAB staff as advisors (Martin et al. 2009; Sosovele 2014). It was also amid this climate of growing criticism that the CEO of SEKAB started to describe the project in terms of a BECCS system (Swedish Radio 2009), something which had not been part of the original plans, and the authors of this paper have been unable to find documents or project plans that can verify any concrete measures being taken towards that end.

The long delays, the land conflicts and the withdrawal of key investors meant that the project never got off the ground. Thus, the SEKAB case highlights the vulnerability of both investors and local communities to the vicissitudes of the market and other external forces, as well as the difficulties in fulfilling the theoretical potential of large-scale biofuel plantations in practical action.

All in all, the experiences of biofuel developments, and also large-scale agro investments in general, in Tanzania in recent years have been largely negative (Engström 2018). They thus risk compounding a legacy of distrust among local communities towards largescale industrial projects that stems from the experiments with "scientific agriculture" under Nyerere, the first President of independent Tanzania (Arora et al. 2013). The government received severe criticism for prioritizing foreign interests over domestic development (Sosovele 2014). Indications of a policy reorientation under the new President Magufuli towards increased state control over natural resources and active industrial policy could be understood as a backlash against the neoliberal policies that have been geared towards easing the access of foreign capital (Jacob and Pedersen 2018; Woodroffe et al. 2017).

\section{Discussion}

In this concluding discussion, we will reconnect the literature review to our analytical framework and reflect on the preconditions for BECCS systems in Tanzania, with focus on the ethanol industry and the country as a supplier of biomass to developed countries, in terms of institutions, market formation and advocacy groups (Jacobsson and Lauber 2006).

\subsection{Institutions}

Despite theoretically good preconditions for BECCS in Tanzania (e.g. Harper et al. 2018; Mwansasu and Westerberg 2014) and a stable regime of governance compared to many developing countries (Wieczorek 2018), the dynamic between formal and informal institutions is presently not conducive to the kind of large-scale biofuel/biomass operations that a BECCS system would necessitate. Among important informal institutions that the literature points to are the lack of trust towards both government and foreign investors as well as ad hoc and informal governance in the absence of formal institutions, which makes land planning processes unpredictable and prone to conflict. The inadequacy of formal institutions in the regulation of land use poses a serious question about the viability of BECCS 
in Tanzania, given that the theoretical potential for net negative emissions can easily translate into net positive emissions due to land use change (Harper et al. 2018). The experiences from large-scale biofuel projects to date indicate a great risk of projects proving to be counterproductive, from both a mitigation perspective and a poverty reduction perspective (see also Engström 2018; Newell and Phillips 2016).

Several formal institutions that offer theoretical support for BECCS are less promising when viewed from practical experience. The CDM mechanism has so far failed to support any CCS project, while REDD+ projects have a low rate of success (Koch 2017; McAfee 2016). The IPCC accounting guidelines could incentivize BECCS as it allows accounting for negative emissions in national greenhouse gas inventories. However, the government of Tanzania is under no pressure to deliver ambitious emissions reductions. Therefore, the implementation of a BECCS system in Tanzania, and other developing countries, would be most likely to emanate from initiatives in developed countries (Honegger and Reiner 2018), driven by either aid or commercial logic. As the literature review shows, aid programmes in their current structure are unlikely to facilitate BECCS in Tanzania. NAMAs, REDD+ and climate-related official development aid are characterized by a donor logic that is unfit for BECCS purposes. BECCS demands long-term capital commitments both for initial investments and to compensate for the additional operational costs (Moreira et al. 2016), but donors generally seek to avoid institutionalizing and sustaining aid over longer periods of time (Fridahl et al. 2015). Furthermore, Marquardt et al. (2016) argue that aid organizations are unlikely to drive energy transitions in developing countries if the programme is not closely aligned with the overarching governmental energy strategy (see also Kamp and Vanheule 2015; Verbong et al. 2010). At present, BECCS is a poor fit in this context, even though expanding the domestic demand of ethanol for cooking and transport theoretically could add momentum to BECCS development supported by international aid.

\subsection{Market formation}

Commercial logic seems similarly unlikely to drive BECCS implementation in Tanzania under current conditions. The only potential value of BECCS lies in its "production" of negative emissions, and its commercial viability is therefore dependent on a functional market for carbon credits that also includes negative emissions. At present, the prospect of a carbon market with prices high enough to justify the large capital and operational costs associated with BECCS on a purely commercial basis seems distant.

Large-scale ethanol production for export is vulnerable to external regulation and market swings, and would be more commercially appealing if there was also a domestic market demand in Tanzania. Here, the government could move to create demand by stimulating domestic use of ethanol as a fuel for cooking and transportation. Arora et al. (2013) point to the absence of governmental support through market subsidies as one important reason why jatropha production failed (see also Nygaard and Bolwig 2018). The willingness of the current government to pursue an active industrial policy, including by banning the import of sugar, points to such a market formation being possible (The Citizen 2016). However, the question remains how BECCS could be implemented in such a technical system as anything but a burden on production.

Historically, an important barrier to the development of production capacity of liquid biofuels for export purposes has been given by ethical dilemmas following in the wake of demand for land to facilitate production of biomass, such as sugarcane and jatropha. In these cases, conflicts over access to land and mismanagement have been more of a rule 
than an exception. Increased production volumes of solid biomass for export to operations that demand bioenergy, be it with or without a CCS component, is likely to give rise to similar conflicts.

\subsection{Advocacy groups and entry of firms}

Even though the IPCC accounting guidelines allow negative emissions to be accounted for in national greenhouse gas inventories, providing an opportunity for states to use BECCS for compliance with international obligations, the typical BECCS operator, i.e. subnational entities or businesses, is not incentivized to do so by national demand side policy. This fact would make it all the more difficult to generate the kind of market and learning dynamics that the entry of new firms into the formation process of a new technical system brings in relation to BECCS. Furthermore, given the recent history of poorly executed and controversial biofuels projects in Tanzania and the risk of land or forest degradation, it would be difficult to garner the kind of broad-based support among stakeholders that is important for a new technical system to take hold (Hansen and Nygaard 2014; van Welie and Romijn 2018). On a more general level, it is also important to highlight that BECCS lacks a strong advocacy group overall, and perhaps most importantly among the industries and actors that would supposedly be the first to implement it, such as pulp and paper and biofuel producers. This latter fact makes its vast deployment in even the more recently published and updated IAM studies (Harper et al. 2018) all the more conspicuous.

\section{Conclusions}

To conclude, the most viable path creation options for large-scale BECCS deployment in Tanzania would be either in the context of ethanol production, or with Tanzania acting as supplier of biomass in an international BECCS system. The external preconditions for either option-commercial or regulatory incentives for negative emissions, or sustained investments through aid programmes or other international sources of finance-are currently lacking. More importantly, the review of historical experiences from biofuel investments in Tanzania reveals that the lack of adequate domestic institutions often occasions land-grabs, land-use conflicts, corruption, technical challenges, lacking infrastructure and resource trade-offs. The institutional vacuum, or dysfunctionality, would further make the needed monitoring and verification of dedicated biomass plantations difficult.

On the basis of our review, we would therefore argue that negative BECCS-related emissions from Tanzania should not be assumed in global climate mitigation scenarios. Furthermore, assuming Tanzania to contribute to negative emissions in estimations of the global carbon budget has problematic spatial and temporal ethical implications. First, it entrenches a view of sub-Saharan African soil as open for appropriation by developed countries in a global system of uneven exchange. As experiences from previous biofuel projects show, local livelihoods are jeopardized both by mistaken assumptions of marginal land and by being connected to a volatile world market.

Second, because scenarios can shape perceptions of what is politically feasible (Beck and Mahony 2018; also Anderson and Peters 2016; Geden 2015), setting climate policy objectives on the basis of assuming Tanzania and other similar countries to play a role in delivering negative emissions risks leads to carbon lock-in and delaying more urgent emissions reductions. Vulnerable countries like Tanzania are the ones most directly at risk 
for climate change induced hazards. Thus, implicating LDCs in a role of delivering negative emissions in the global carbon budget amounts to nothing less than collateralising the countires' future in what Carton (2019) has termed "the political economy of delay" (p. 765).

While BECCS may well play an important role in reducing emissions in countries with high capacity to act combined with existing large point sources of biogenic $\mathrm{CO}_{2}$ emissions (Gough et al. 2018a, b), it seems prudent to proceed with utmost caution when implicating BECCS deployment in LDCs, like Tanzania. It also seems reasonable to argue that largescale biomass-based energy supply, be it for use with or without CCS, implicating massive land use in LDCs should not be assumed other than in cases that are grounded in deeper contextual case-by-case analysis.

Acknowledgements Open access funding provided by Linköping University. The research was funded jointly by the Swedish Research Council and Sida through the Swedish Government's development aid funds, and by Formas' and Forte's research appropriations (Sustainability and Resilience - Tackling Climate and Environmental Changes [2016-06359]).

Open Access This article is distributed under the terms of the Creative Commons Attribution 4.0 International License (http://creativecommons.org/licenses/by/4.0/), which permits unrestricted use, distribution, and reproduction in any medium, provided you give appropriate credit to the original author(s) and the source, provide a link to the Creative Commons license, and indicate if changes were made.

\section{References}

African Development Bank Group. (2015). Renewable energy in Africa: Tanzania Country profile. Abidjan: African Development Bank Group.

Aly, A., Jensen, S., \& Pedersen, A. (2017). Solar power potential of Tanzania: Identifying CSP and PV hot spots through a GIS multicriteria decision making analysis. Renewable Energy, 113, 159-175.

Amars, L., Fridahl, M., Hagemann, M., Röser, F., \& Linnér, B.-O. (2017). The transformative potential of Nationally Appropriate Mitigation Actions in Tanzania: Assessing the concept's cultural legitimacy among stakeholders in the solar energy sector. Local Environment, 22(1), 86-105.

Anderson, K., \& Peters, G. (2016). The trouble with negative emissions. Science, 354, 182-183.

Arora, S., Romijn, H., \& Caniels, M. (2013). Governed by history: Institutional analysis of a contested biofuel innovation system in Tanzania. Industrial and Corporate Change, 23(2), 573-607.

Beck, S., \& Mahony, M. (2018). The IPCC and the new map of science and politics. WIREs Climate Change, 9(6), e547.

Bellamy, R., \& Healey, P. (2018). 'Slippery slope' or 'uphill struggle'? Broadening out expert scenarios of climate engineering research and development. Environmental Research \& Policy, 83, 1-10.

Bergius, M., Benjaminsen, T., \& Widgren, M. (2018). Green economy, Scandinavian Investments and Agricultural Modernization in Tanzania. Journal of Peasant Studies, 45(4), 825-852.

Bhati, P., \& Koshy, M. (2018). Analysis of Tanzania's power system master Plan 2016. New Delhi: Centre for Science and Environment.

Blomley, T., Pfliegner, K., Isango, J., et al. (2008). Seeing the wood for the trees: An assessment of the impact of participatory forest management on forest condition in Tanzania. Oryx, 42(3), 380-391.

Boesen, J., Sosovele, H., \& Maganga, F. H. (2018). Social and environmental impact of irrigation farming in Tanzania: Selected cases. Dar es Salaam University Press (DUP)

Brüntrup, M., Absmayr, T., Dylla, J., Eckhard, F., Remke, K., \& Sternisko, K. (2016). Large-scale agricultural investments and rural development in Tanzania: lessons learned, steering requirements and policy responses. Paper prepared for presentation at the "2016 WORLD BANK CONFERENCE ON LAND AND POVERTY" The World Bank-Washington DC, March 14-18, 2016 German Development Institute/Deutsches Institut für Entwicklungspolitik (DIE), Germany. Retrieved October 10, 2018 from https://www.die-gdi.de/uploads/media/Bruentrup-230-230_paper.pdf.

Buck, H. J. (2016). Rapid scale-up of negative emissions technologies: Social barriers and social implications. Climatic Change, 139(2), 155-167. 
Bui, M., Fajardy, M., \& Mac Dowell, N. (2017). Bio-Energy with CCS (BECCS) performance evaluation: Efficiency enhancement and emissions reduction. Applied Energy, 195, 289-302.

Carton, W. (2019). "Fixing" Climate change by mortgaging the future: Negative emissions, spatiotemporal fixes, and the political economy of delay. Antipode. https://doi.org/10.1111/anti.12532.

Creutzig, F., Ravindranath, G., Berndes, S., Bolwig, R., Bright, F., Cherubini, F., et al. (2015). Bioenergy and climate change mitigation: An assessment. Global Change Biology: Bioenergy, 7, 916-944.

Demirbas, A. (2003). Sustainable co-firing of biomass with coal. Energy Conversion and Management, 44, 1465-1479.

Dixon, T., Leamon, G., Zakkour, P., \& Warren, L. (2013). CCS projects as Kyoto protocol CDM activities. Energy Procedia, 37, 7596-7604.

Edquist, C. (Ed.). (1997). Systems of innovation: Technologies, institutions, and organizations. London: Pinter.

Engström, L. (2018). Development delayed: Exploring the failure of a large-scale agricultural investment in Tanzania to deliver promised outcomes. Doctoral Thesis No. 2018:40. Uppsala: Faculty of Natural Resources and Agricultural Sciences, Uppsala University.

Eshton, B., \& Katima, J. (2015). Carbon footprints of production and use of liquid biofuels in Tanzania. Renewable and Sustainable Energy Reviews, 42, 672-680.

Everingham, Y. L., Muchow, R. C., Stone, R. C., Inman-Bamber, N. G., Singels, A., \& Bezuidenhout, C. N. (2002). Enhanced risk management and decision-making capability across the sugarcane industry value chain based on seasonal climate forecasts. Agricultural Systems, 74(3), 459-477.

Exner, A., Bartels, L. E., Windhaber, M., Fritz, S., See, L., Politti, E., et al. (2015). Constructing landscapes of value: Capitalist investment for the acquisition of marginal or unused. Land Use Policy, 42, 652-663.

Felix, M., \& Gheewala, S. H. (2011). A review of biomass energy dependency in Tanzania. Energy Procedia, 9, 338-343.

Felix, M., \& Gheewala, S. H. (2012). Environmental assessment of electricity production in Tanzania. Energy for Sustainable Development, 16(4), 439-447.

Franke, B., Gärtner, S., Köppen, S., Reinhardt, G., \& Gordon-Maclean, A. (2010). Bioenergy Environmental Impact Analysis (BIAS) of ethanol production from sugar cane in Tanzania, Case Study: SEKAB/Bagamoyo (Vol. 47)., Environment and Natural Resources Management Series Rome: FAO.

Freeman, C. (1986). The economics of industrial innovation. Cambridge, MA: MIT Press.

Fridahl, M., Hagemann, M., Röser, F., \& Amars, L. (2015). A comparison of design and support priorities of Nationally Appropriate Mitigation Actions (NAMAs). The Journal of Environment \& Development, 24(2), 237-264.

Fuss, S., Canadell, J. G., Peters, G. P., Tavoni, M., Andrew, R. M., Ciais, P., et al. (2014). Betting on negative emissions. Nature Climate Change, 4(10), 850-853.

Gasparatos, A., von Maltitz, G. P., Johnson, F. X., Lee, L., Mathai, M., Puppim de Oliveira, J. A., et al. (2015). Biofuels in sub-Sahara Africa: Drivers, impacts and priority policy areas. Renewable and Sustainable Energy Reviews, 45, 879-901.

Geden, O. (2015). Climate Advisers must maintain integrity. Nature, 521, 27-28.

Geels, F. W. (2012). A socio-technical analysis of low-carbon transitions: introducing the multi-level perspective into transport studies. Journal of Transport Geography, 24, 471-482.

Global CCS Institute. (2015). Carbon capture and storage in the community of Portuguese language countries: Opportunities and challenges. Évora: Escola de Ciências e Tecnologia, Universidade de Évora.

Gough, C., Garcia-Freites, S., Jones, C., Mander, S., Moore, B., Pereira, C., et al. (2018a). Challenges to the use of BECCS as a keystone technology in pursuit of $1.5^{\circ}$ C. Global Sustainability, 1(e5), 1-9.

Gough, C., Mabon, L., \& Mander, S. (2018b). Social and ethical dimensions of BECCS. In C. Gough, et al. (Eds.), Biomass energy with carbon capture and storage (BECCS): Unlcoking negative emissions. Singapore: Wiley.

Government of Tanzania. (1999). The Tanzania Development Vision 2025. Dar es Salaam: United Republic of Tanzania, President's Office, Planning Comission. Retrieved September 3, 2018 from www.mof.go.tz/mofdocs/overarch/vision2025.htm.

Government of Tanzania. (2012). The Tanzania Long-Term Perspective Plan (LTPP) 2011/12-2025/26: The Roadmap to a Middle Income Country. Dar es Salaam: United Republic of Tanzania, President's Office. Retrieved September 3, 2018 from www.mipango.go.tz.

Greif, A. (2006). Institutions and the path to the modern economy: Lessons from medieval trade. Cambridge: Cambridge University Press. 
Greiner, S., Howard, A., Chagas, T., \& Hunzai, T. (2017). CDM transition to Article of the Paris Agreement: Options report. Koru Climate/Climate Focus. Retrieved October 3, 2018 from https://clima tefocus.com/publications/cdm-transition-article-6-paris-agreement-options-report.

Grönkvist, S., et al. (2010). System study of the possibilities for the implementation of an infrastructure for CCS in the Baltic Sea region. Swedish Energy Agency, ER 2010:36, ISSN 1403-1892.

Guillemot, H. (2017). The necessary and inaccessible $1.5^{\circ} \mathrm{C}$ objective: A turning point in the relations between climate science and politics? In S. C. Aykut, J. Foyer, \& E. Morena (Eds.), Globalising the Climate: COP21 and the Climatisation of Global Debates. Abingdon: Routledge.

Habib-Mintz, N. (2010). Biofuel investment in Tanzania: Omissions in implementation. Energy Policy, 38(8), 3985-3997.

Hansen, U., \& Nygaard, I. (2014). Sustainable energy transitions in emerging economies: The formation of a palm oil biomass waste-to-energy niche in Malaysia 1990-2011. Energy Policy, 66, 666-676.

Hansen, U., Nygaard, I., Romijn, H., Wieczorek, A., Kamp, L., \& Klerk, L. (2018). Sustainability transitions in developing countries: Stocktaking, new contributions and a research agenda. Environmental Science \& Policy, 84, 198-203.

Harnesk, D., \& Brogaard, S. (2016). Social dynamics of renewable energy-How the European Union's renewable energy directive triggers land pressure in Tanzania. Journal of Environment \& Development, 26(2), 156-185.

Harper, A. B., et al. (2018). Land-use emissions play a critical role in land-based mitigation for Paris climate targets. Nature Communications, 9, 2938.

Haszeldine, R. S. (2006). Deep geological $\mathrm{CO}_{2}$ storage: Principles reviewed, and prospecting for bio-energy disposal sites. Mitigation and Adaptation Strategies for Global Change, 11, 377-401.

Honegger, M., \& Reiner, D. (2018). The political economy of negative emissions technologies: Consequences for international policy design. Climate Policy, 18(3), 306-321.

Hultman, N. E., et al. (2012). Biofuels Investments in Tanzania: Policy options for sustainable business models. The Journal of Environment \& Development, 21(3), 339-361.

Hundsbaek Pedersen, R., \& Bofin, P. (2019). Muted market signals: Politics, petroleum investments and regulatory developments in Tanzania. Journal of Eastern African Studies. https://doi.org/10.1080/17531 055.2019.1605770.

Jacob, T., \& Brockington, D. (2017). Learning from the other: Benefit sharing lessons for REDD+implementation based on CBFM experience in Northern Tanzania. Land Use Policy. https://doi. org/10.1016/j.landusepol.2017.10.028.

Jacob, T., \& Pedersen, R. (2018). New resource nationalism? Continuity and change in Tanzania's extractive industries. The Extractive Industries and Society, 5(2), 287-292.

Jacobsson, S., \& Lauber, V. (2006). The politics and policy of energy system transformation-Explaining the German diffusion of renewable energy technology. Energy Policy, 34, 256-276.

Jönsson, J., \& Berntsson, T. (2012). Analysing the potential for implementation of CCS within the European pulp and paper industry. Energy, 44(1), 641-648.

Jumbe, C. B. L., Frederick, B. M., Msiska, F. B. M., \& Madjera, M. (2009). Biofuels development in SubSaharan Africa: Are the policies conducive? Energy Policy, 37, 4980-4986.

Kamp, L., \& Vanheule, L. (2015). Review of the small wind turbine sector in Kenya: Status and bottle necks for growth. Renewable and Sustainable Energy Reviews, 49, 470-480.

Karnøe, P., \& Garud, R. (2012). Path creation: Co-creation of heterogeneous resources in the emergence of the Danish wind turbine cluster. European Planning Studies, 20(5), 733-752.

Kashaigili, J. J., \& Nzunda, E. F. (2010). Impact of biofuels on human development: A case study of Bagamoyo and Kisarawe districts in Tanzania. Morogoro: Sokoine University of Agriculture.

Kemper, J. (2015). Biomass and carbon dioxide capture and storage: A review. International Journal of Greenhouse Gas Control, 40, 401-430.

Kichonge, B. (2018). The status and future prospects of hydropower for sustainable water and energy development in Tanzania. Journal of Renewable Energy. https://doi.org/10.1155/2018/6570358.

Kijazi, M. H., Joel, J. I., Larson, A. M., \& Cisneros, N. (2017). Multilevel governance, carbon management and land-use decisions in Tanzania. Working Paper 226. Bogor: CIFOR.

Koch, S. (2017). International influence on forest governance in Tanzania: Analysing the role of aid experts in the REDD+ process. Forest Policy and Economics, 83, 181-190.

Lawhon, M., \& Murphy, J. (2012). Socio-technical regimes and sustainability transitions: Insights from political ecology. Progress in Human Geography, 36(3), 354-378.

Locher, M., \& Sulle, E. (2013). Foreign land deals in Tanzania: An update and a critical view on the challenges of data (re)production. Cape Town: LDPI Working Paper 31. Institute for Poverty, Land and Agrarian Studies. University of the Western Cape. 
Lund, C., Odgaard, R., \& Sjaastad, E. (2006). Land rights and land conflicts in Africa: A review of Issues and Experiences. Copenhagen: Danish Institute for International Studies.

Lund, J., et al. (2017). Promising change, delivering continuity: REDD + as conservation fad. World Development, 89, 124-139.

Markard, J., Raven, R., \& Truffer, B. (2012). Sustainability transitions: An emerging field of research and its prospects. Research Policy, 41, 955-967.

Marquardt, J., Steinbacher, K., \& Schreurs, M. (2016). Driving force or forced transition? The role of development cooperation in promoting energy transitions in the Philippines and Morocco. Journal of Cleaner Production, 128, 22-33.

Martin, M., Mwakaje, A., \& Eklund, M. (2009). Biofuel development initiatives in Tanzania: Development activities, scales of production and conditions for implementation and utilization. Journal of Cleaner Production, 17, 569-576.

Massay, G., (2016). Tanzania's village land Act 15 years on. Rural, 03/2016. Retrieved October 9, 2018 from https://www.tnrf.org/files/pubs/land_act.pdf.

McAfee, K. (2016). Green economy and carbon markets for conservation and development: A critical view. International Environmental Agreements: Politics, Law and Economics, 16(3), 333-353.

Metcalfe, J., \& Cantner, U. (Eds.). (2003). Change, transformation and development. Heidelberg: PhysicaVerlag (Springer).

Moreira, J. R., Romeiro, V., Fuss, S., Kraxner, F., \& Pacca, S. A. (2016). BECCS potential in Brazil: Achieving negative emissions in ethanol and electricity production based on sugar cane bagasse and other residues. Applied Energy, 179, 55-63.

Mshandete, A. M. (2011). Biofuels in Tanzania: Status, opportunities and challenges. Journal of Applied Biosciences, 40, 2677-2705.

Msyani, C. (2013). Current status of energy sector in Tanzania. Presentation at USEA, Washington D.C. 25 February-2 March. Retrieved October 9, 2018 from https://www.usea.org/sites/default/files/event-/ Tanzania\%20Power\%20Sector.pdf.

Mwakaje, G. (2012). Can Tanzania realise rural development through biofuel plantations? Insights from the study in Rufiji District. Energy for Sustainable Development, 16, 320-327.

Mwansasu, S. L. A., \& Westerberg, L. O. (2014). Biofuel potential and land availability: The case of Rufiji District, Tanzania. Journal of Ecology and the Natural Environment, 6(11), 389-397.

Nantongo, M. G. (2017). Legitimacy of local REDD + processes: A comparative analysis of pilot projects in Brazil and Tanzania. Environmental Science \& Policy, 78, 81-88.

Newell, P., \& Phillips, J. (2016). Neoliberal energy transitions in the South: Kenyan experiences. Geoforum, $74,39-48$.

North, D. C. (2005). Understanding the process of economic change. Princeton: Princeton University Press.

Nygaard, I., \& Bolwig, S. (2018). The rise and fall of foreign private investment in the jatropha biofuel value chain in Ghana. Environmental Science \& Policy, 84, 224-234.

Odhiambo, N. M. (2009). Energy consumption and economic growth nexus in Tanzania: An ARDL bounds testing approach. Energy Policy, 37(2), 617-622.

Okonko, I. O., Adeola, O. T., Aloysius, T. E., \& Oluseyi, A. (2009). Utilization of food wastes for sustainable development. Electronic Journal of Environment Agriculture and Food Chemistry, 8, 263-286.

Olwiga, M. F., Noeb, C., Kangalawec, R., \& Luogad, E. (2015). Inverting the moral economy: The case of land acquisitions for forest plantations in Tanzania. Third World Quarterly, 36(12), 2316-2336.

Peters, G. P., \& Geden, O. (2017). Catalysing a political shift from low to negative carbon. Nature Climate Change, 7, 619-621.

Quintero, J. A., Cardona, C. A., Felix, E., Moncada, J., Sánchez, Ó. J., \& Gutiérrez, L. F. (2012). Technoeconomic analysis of bioethanol production in Africa: Tanzania case. Energy, 48(1), 442-454.

Rajcaniova, M., Drabik, D., \& Ciaian, P. (2013). How policies affect international biofuel price linkages. Energy Policy, 59, 857-865.

Rascack, B. (2014). Forest Reform in Tanzania: A review of Policy and Legislation. African Journal of Economic Review, 11(2), 125-149.

Renzaho, M., Kamara, J., \& Toole, M. (2017). Biofuel production and its impact on food security in low and middle income countries: Implications for the post-2015 sustainable development goals. Renewable and Sustainable Energy Reviews, 78, 503-516.

Riahi, K., van Vuuren, D. P., Kriegler, E., Edmonds, J., O’Neill, B. C., Fujimori, S., et al. (2017). The shared socioeconomic pathways and their energy, land use, and greenhouse gas emissions implications: An overview. Global Environmental Change, 42, 153-168.

Romijn, H. A. (2009). Land Clearing and Greenhouse Gas Emissions from Jatropha Biofuels on African Miombo Woodland. Retrieved October 9, 2018 from http://www.factfoundation.com/en/Knowledge_ Centre/News/Recent_news/GHG_emissions_from_land_use_change_for_Jatropha. 
Romijn, H. A., \& Caniels, M. C. J. (2011). The Jatropha biofuels sector in Tanzania 2005-2009: Evolution towards sustainability? Research Policy, 40(4), 618-636.

Sasol. (2018). Sasol limited climate change. Disclosure Insight Action (CDP). Retrieved June 5, 2019 from https://www.sasol.com/sites/default/files/financial_reports/CDP\%20Submission\%202018.pdf.

Sheya, M. S., \& Mushi, S. J. S. (2000). The state of renewable energy harnessing in Tanzania. Applied Energy, 65, 257-271.

Sixt, G., Klerkx, L., \& Griffin, T. (2018). Transitions in water harvesting practices in Jordan's rainfed agricultural systems: Systemic problems and blocking mechanisms in an emerging technological innovation system. Environmental Science \& Policy, 84, 235-249.

Smith, A., Stirling, A., \& Berkhout, F. (2005). The governance of sustainable socio-technical transitions. Research Policy, 34, 1491-1510.

Sosovele, H. (2014). Moratorium in biofuel development projects in Tanzania: The need for policies, guidelines and sustainability criteria. Journal of the Geographical Association of Tanzania, 34, 1-2.

Sulle, E., \& Nelson, F. (2009). Biofuels, land access and rural livelihoods in Tanzania. London: IIED.

Sulle, E., \& Nelson, F. (2013). Biofuels Investment and Community Land Tenure in Tanzania. Tanzania National Resource Forum. London: IIED.

Swedish Radio. (2009). Svensk nykolonialism eller Tanzanias räddare? Sveriges Radio P1/Klotet. Retrieved October 9, 2018 from https://sverigesradio.se/sida/artikel.aspx ?programid=3345\&artikel=2595114.

Tenga, R. W. (2015). Tanzania: LGAF synthesis report. Washington, DC: Worlds Bank.

The Citizen. (2016). Politics of sugar: First toughest test Magufuli govt to face head. Retrieved October 9 , 2018 from http://www.thecitizen.co.tz/News/1840340-3223694-kqs1 vaz/index.html.

Thurlow, J., Branca, G., Felix, E., Maltsoglou, I., \& Rincón, L. E. (2016). Producing biofuel in low-income countries: An integrated environmental and economic assessment for Tanzania. Environmental \& Resource Economics, 64(2), 153-171.

URT. (2014). Second national communication to the United Nations framework convention on climate change. Dar es Salaam, Vice President's Office.

URT. (2017). Tanzania forest emission reference level submission to the United Nations framework convention on climate change (UNFCCC). Dar es Salaam, Vice President's Office.

van Assche, K., Beunen, R., \& Duineveld, M. (2014). Evolutionary governance theory: An introduction. New York: Springer.

van Eijck, J., Romijn, H., Smeets, E., Bailis, R., Rooijakkers, M., Hooijkaas, N., et al. (2014). Comparative analysis of key socio-economic and environmental impacts of smallholder and plantation based jatropha biofuel production systems in Tanzania. Biomass and Bioenergy, 61, 25-45.

Van Welie, M., \& Romijn, H. (2018). NGOs fostering transitions towards sustainable urban sanitation in low-income countries: Insights from Transition Management and Development Studies. Environmental Science \& Policy, 84, 250-260.

Verbong, G., Christiaens, W., Raven, R., \& Balkema, A. (2010). Strategic Niche management in an unstable regime: Biomass gasification in India. Environmental Science \& Policy, 13(4), 272-281.

Vermeulen, S., \& Cotula, L. (2010). Over the heads of local people: Consultation, consent, and recompense in large- scale land deals for biofuels projects in Africa. The Journal of Peasant Studies, 37(4), 899-916.

Widengård, M., Nightingale, A., Roberntz, P., et al. (2018). Seeing Like a Standard: EU, sustainable biofuels, and land use change in Africa. ACME: An International E-Journal for Critical Geographies, 17, 49-87.

Wieczorek, A. (2018). Sustainability transitions in developing countries: Major insights and their implications for research and policy. Environmental Science \& Policy, 84, 204-216.

Williams, R. H., \& Larsen, E. D. (2012). CMI Biomass energy with carbon capture and storage (BECCS): Strategies for reducing carbon footprint of the oil industry. Princeton: Environmental Institute. Retrieved October 9, 2018 from https://cmi.princeton.edu/news/pdfs/Larson_BECCS.pdf.

Willoughby, R. (2014). Moral hazard? 'Mega' public-private partnerships in African agriculture. Nairobi: Oxfam international, Oxfam Briefing Paper No. 188.

Woodroffe, N., Genasci, M., \& Scurfield, T. (2017). Tanzania's new natural resource legislation: What will change? NRGI Briefing. New York: Natural Resource Governance Institute. Retrieved October 9, 2018 from https://resourcegovernance.org/sites/default/files/documents/tanzania-new-natural-legis lation-what-will-change.pdf.

Yanda, P., et al. (2013). Tanzania national climate change finance analysis: Shaping policy for development. London and Dar es Salaam: Overseas Development Institute and the Centre for Climate Change Studies, University of Dar es Salaam.

Zakkour, P., Kemper, J., \& Dixon, T. (2014). Incentivising and accounting for negative emission technologies. Energy Procedia, 63, 6824-6833. 
Zirulnick, A. (2015). Tanzania sugar project leaves bitter taste for farmers caught up in land disputes. The Guardian, 21 October 2015.

Publisher's Note Springer Nature remains neutral with regard to jurisdictional claims in published maps and institutional affiliations.

\section{Affiliations}

Anders Hansson ${ }^{1} \cdot$ Mathias Fridahl ${ }^{1} \cdot$ Simon Haikola ${ }^{2} \cdot$ Pius Yanda $^{3} \cdot$ Noah Pauline $^{3}$. Edmund Mabhuye ${ }^{3}$

Anders Hansson

anders.n.hansson@liu.se

1 Department of Thematic Studies: Environmental Change \& Centre for Climate Science and Policy Research, Linköping University, Linköping, Sweden

2 Department of Thematic Studies: Technology and Social Change \& Centre for Climate Science and Policy Research, Linköping University, Linköping, Sweden

3 Institute of Resource Assessment, University of Dar Es Salaam, Dar Es Salaam, Tanzania 